\title{
The features of infectious diseases departments and anti-infective practices in France and Turkey: a cross-sectional study
}

\author{
H. Erdem • J. P. Stahl • A. Inan • S. Kilic • M. Akova • C. Rioux • I. Pierre • A. Canestri • \\ E. Haustraete • D. O. Engin • E. Parlak • X. Argemi • D. Bruley • E. Alp • S. Greffe • \\ S. Hosoglu • S. Patrat-Delon • Y. Heper • M. Tasbakan • V. Corbin • M. Hopoglu • \\ I. I. Balkan • B. Mutlu • E. Demonchy • H. Yilmaz • C. Fourcade • L. Toko-Tchuindzie • \\ S. Kaya • A. Engin - A. Yalci • C. Bernigaud - H. Vahaboglu • E. Curlier • D. Akduman • \\ A. Barrelet • S. Oncu • V. Korten • G. Usluer • H. Turgut • A. Sener • O. Evirgen • N. Elaldi • \\ L. Gorenek
}

Received: 19 January 2014 / Accepted: 8 April 2014 /Published online: 1 May 2014

(C) Springer-Verlag Berlin Heidelberg 2014

\begin{abstract}
The aim of this study was to assess the infectious diseases (ID) wards of tertiary hospitals in France and Turkey for technical capacity, infection control, characteristics of patients, infections, infecting organisms, and therapeutic approaches. This cross-sectional study was carried out on a single day on one of the weekdays of June 17-21, 2013. Overall, 36 ID departments from Turkey $(n=21)$ and France
\end{abstract}

\section{H. Erdem $(\bowtie) \cdot$ L. Gorenek}

Department of Infectious Diseases and Clinical Microbiology, GATA

Haydarpasa Training Hospital, Istanbul, Turkey

e-mail: hakanerdem1969@yahoo.com

\section{J. P. Stahl}

Department of Infectious Diseases, Joseph Fourier University and

University Hospital of Grenoble, Grenoble, France

A. Inan · D. O. Engin

Department of Infectious Diseases and Clinical Microbiology,

Haydarpasa Numune Training and Research Hospital, Istanbul,

Turkey

S. Kilic

Department of Public Health, Gulhane Medical Academy, Ankara,

Turkey

M. Akova

School of Medicine, Infectious Diseases Unit, Hacettepe University, Ankara, Turkey

C. Rioux

Department of Infectious Diseases, Bichat University Hospital, Paris, France

I. Pierre

Department of Infectious Diseases, Hospital Raymond Poincaré,

Garches, France $(n=15)$ were involved. On the study day, 273 patients were hospitalized in Turkish and 324 patients were followed in French ID departments. The numbers of patients and beds in the hospitals, and presence of an intensive care unit (ICU) room in the ID ward was not different in both France and Turkey. Bed occupancy in the ID ward, single rooms, and negative pressure rooms were significantly higher in France.

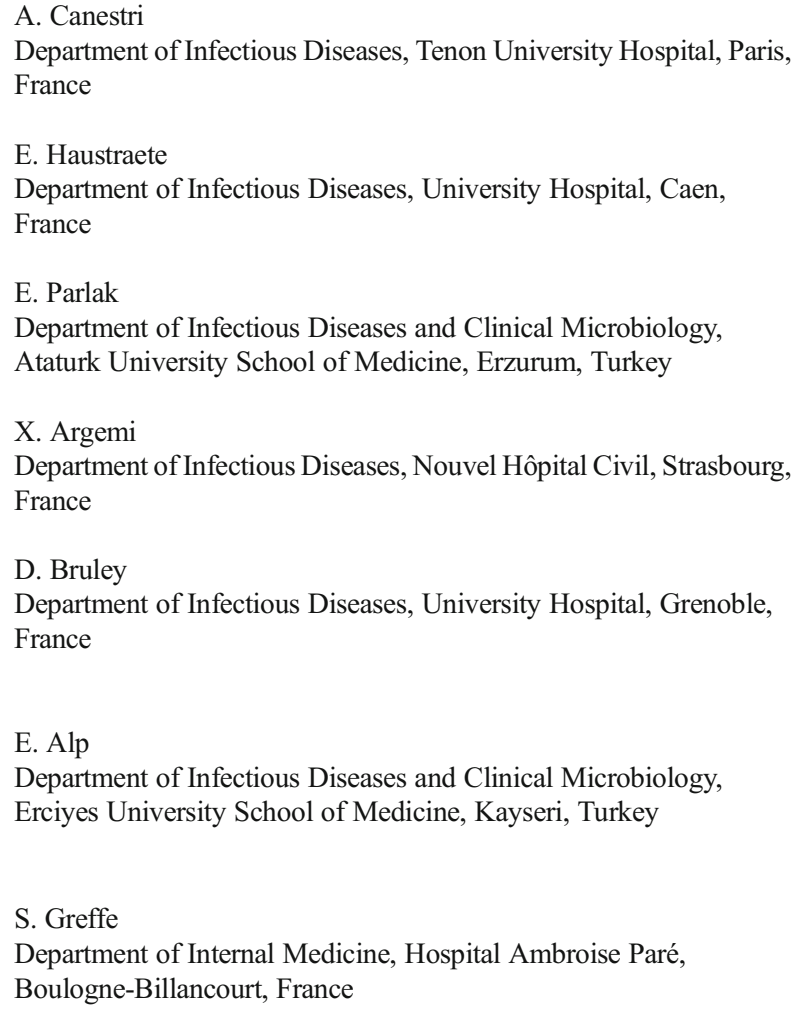


The presence of a laboratory inside the ID ward was more common in Turkish ID wards. The configuration of infection control committees, and their qualifications and surveillance types were quite similar in both countries. Although differences existed based on epidemiology, the distribution of infections were uniform on both sides. In Turkey, anti-Grampositive agents, carbapenems, and tigecycline, and in France, cephalosporins, penicillins, aminoglycosides, and metronidazole were more frequently preferred. Enteric Gram-negatives and hepatitis $\mathrm{B}$ and $\mathrm{C}$ were more frequent in Turkey, while human immunodeficiency virus (HIV) and streptococci were more common in France ( $p<0.05$ for all significances). Various differences and similarities existed in France and Turkey in the ID wards. However, the current scene is that ID are managed with high standards in both countries.

\section{Introduction}

France and Turkey are two large countries at the Mediterranean basin. The population of France, the largest country in the European Union, is around 66 million today (http://en.wikipedia.org/wiki/Demographics_of_France\#cite_ note-metro-4). Turkey, located at the cross-section of three continents with close linkages to these geographical areas, has a population of 74 million according to 2010 data (http://en.

S. Hosoglu

Department of Infectious Diseases and Clinical Microbiology, Dicle

University School of Medicine, Diyarbakir, Turkey

S. Patrat-Delon

Department of Infectious Diseases, University Hospital, Rennes, France

Y. Heper

Department of Infectious Diseases and Clinical Microbiology,

Uludag University School of Medicine, Bursa, Turkey

M. Tasbakan

Department of Infectious Diseases and Clinical Microbiology, Ege

University School of Medicine, Izmir, Turkey

V. Corbin

Department of Infectious Diseases, University Hospital, Clermont

Ferrand, France

M. Hopoglu

Department of Infectious Diseases and Clinical Microbiology, Inonu University School of Medicine, Malatya, Turkey

I. I. Balkan

Department of Infectious Diseases and Clinical Microbiology,

Istanbul University Cerrahpasa School of Medicine, Istanbul, Turkey

B. Mutlu

Department of Infectious Diseases and Clinical Microbiology,

Kocaeli University School of Medicine, Kocaeli, Turkey
wikipedia.org/wiki/Demographics_of_Turkey\#cite_note-1). France is a developed country and has the world's seventh largest economy. On the other hand, Turkey is a strictly reorganizing country in the last 30 years and has the world's 15th largest economy (http://databank.worldbank.org/data/ download/GDP_PPP.pdf).

The infrastructures and technical capacities of infectious diseases (ID) departments, infection control (IC) and prevention organizations, epidemiology of infections, and antibiotic consumption habits have evolved according to their own historical experiences in both countries. The current designs for these issues are quite interrelated to lots of parameters, including healthcare systems, financial concepts, postgraduate training infrastructures, the epidemiology of infections and resistant pathogens, and the traditional medical point of views. Thus, this cross-sectional study was performed in both Turkey and France to disclose the ongoing ID practices in the ID wards, to delineate the effectiveness of their anti-infective management facilities, and to provide comparisons for these two large countries located at the opposite sides of Europe.

\section{Methods}

This cross-sectional point prevalence study was carried on a single day in June 17-21, 2013. Two questionnaires related to

\author{
E. Demonchy \\ Department of Infectious Diseases, University Hospital, Nice, France \\ H. Yilmaz \\ Department of Infectious Diseases and Clinical Microbiology, \\ Ondokuz Mayis University School of Medicine, Samsun, Turkey

\section{Fourcade} \\ Department of Infectious Diseases, University Hospital, Nîmes, \\ France \\ L. Toko-Tchuindzie \\ Department of Infectious Diseases, General Hospital, Belfort, France \\ S. Kaya \\ Department of Infectious Diseases and Clinical Microbiology, \\ Karadeniz Technical University School of Medicine, Trabzon, \\ Turkey
}

A. Engin $\cdot$ N. Elaldi

Department of Infectious Diseases and Clinical Microbiology,

Cumhuriyet University School of Medicine, Sivas, Turkey

\author{
A. Yalci \\ Department of Infectious Diseases and Clinical Microbiology, \\ Ankara University School of Medicine, Ankara, Turkey \\ C. Bernigaud \\ Department of Infectious Diseases, General Hospital, \\ Chalon-sur-Saône, France
}


patients and ID departments were sent to participant centers. The first questionnaire evaluated the features of technical capacity of the ward and IC organization, along with characteristics of the ward personnel. The second questionnaire assessed the characteristics of patients, the quality of service provided, supportive care, characteristics of ID, infecting microorganisms, and treatment issues.

No data from military hospitals in both countries were enrolled. The cities where the participant centers were located are shown in Fig. 1. On the study day, each hospitalized patient in the ID ward was visited by an ID specialist in each center. The data were inserted into separate MS Office Excel files, one related to the ID ward and the other for patient characteristics. The overall database was produced by merging the individual Excel files.

SPSS 15.0 (SPSS Inc., Chicago, IL, USA) for Windows Evaluation Version was used for the statistical analysis. Descriptive statistics were presented as mean \pm standard deviations, and frequency and percentage. Student's $t$-test was used to compare continuous variables. Pearson's chi-squared or Fisher's exact tests were used to compare categorical variables, as appropriate. A $p$-value of $<0.05$ was accepted as being statistically significant.

\section{Results}

Overall, 36 ID departments from Turkey $(n=21)$ and France $(n=15)$ were involved in this study. On the study day, 273 patients were hospitalized in Turkish and 324 patients were hospitalized in French ID departments. The mean age of the patients was $56.81 \pm 19.42$ years. The mean duration of hospitalization for the patients in the study was $13.78 \pm 34.82$ days. The mean body temperature of the patients on the study day was $36.80 \pm 1.71^{\circ} \mathrm{C}$, and the means of the leukocyte count and

\section{H. Vahaboglu}

Department of Infectious Diseases and Clinical Microbiology,

Medeniyet University, Goztepe Training and Research Hospital,

Istanbul, Turkey

E. Curlier

Department of Infectious Diseases, University Hospital, Besançon, France

D. Akduman

Department of Infectious Diseases and Clinical Microbiology, Bulent Ecevit University School of Medicine, Zonguldak, Turkey

\author{
A. Barrelet \\ Department of Internal and Infectious Diseases, André Mignot \\ Hospital, Versailles, France \\ S. Oncu \\ Department of Infectious Diseases and Clinical Microbiology, Adnan \\ Menderes University School of Medicine, Aydin, Turkey
}

erythrocyte sedimentation rate (ESR) on admission were $11,022.81 \pm 24,191.82 / \mathrm{mm}^{3}$ and $49.13 \pm 40.42 \mathrm{~mm} / \mathrm{h}$, respectively.

\section{Infrastructure of ID wards}

The mean number of patients $(25.6 \pm 13.7$ vs. $13.4 \pm 6.4)$ and the occupancy rate in the ID ward (25.6/25.9 vs. 13.4/18.0) were significantly higher in favor of France ( $p<0.05$ for all). The presence of negative pressure rooms was significantly more frequent in French ID wards compared to Turkish ID wards ( 8 of 15 centers vs. 3 of 21 centers), while the presence of a microbiology laboratory inside the ID wards (15 of 21 centers vs. 3 of 15 centers) was significantly more frequent in Turkey ( $p<0.05$ for both). The features of ID departments are presented in Table 1.

Infection control and prevention

The procedures, quality standards, and requirements related to IC and prevention infrastructures in both countries were apparently comparable. However, both invasive device-related surveillance (21 of 21 centers vs. 10 of 15 centers) and surveillance of immunization for healthcare workers (HCWs) (20 of 21 centers vs. 10 of 15 centers) were performed significantly more frequently in Turkish hospitals $(p<0.05$ for both). The data related to IC are presented in Table 2.

\section{Etiological diagnoses}

There were 248 and 321 infections as the primary diagnoses in Turkey and France, respectively. Bone and joint infections [18 (7.2\%) vs. $47(14.6 \%)$ ], pneumonia [8 (3.2\%) vs. 50 $(15.6 \%)]$, sepsis of unknown origin [11 (4.4\%) vs. 31

V. Korten

Department of Infectious Diseases and Clinical Microbiology,

Marmara University, School of Medicine, Istanbul, Turkey

G. Usluer

Department of Infectious Diseases and Clinical Microbiology,

Osmangazi University School of Medicine, Eskisehir, Turkey

H. Turgut

Department of Infectious Diseases and Clinical Microbiology,

Pamukkale University School of Medicine, Denizli, Turkey

A. Sener

Department of Infectious Diseases and Clinical Microbiology, Onsekiz Mart University School of Medicine, Canakkale, Turkey

O. Evirgen

Department of Infectious Diseases and Clinical Microbiology, Mustafa Kemal University School of Medicine, Hatay, Turkey 


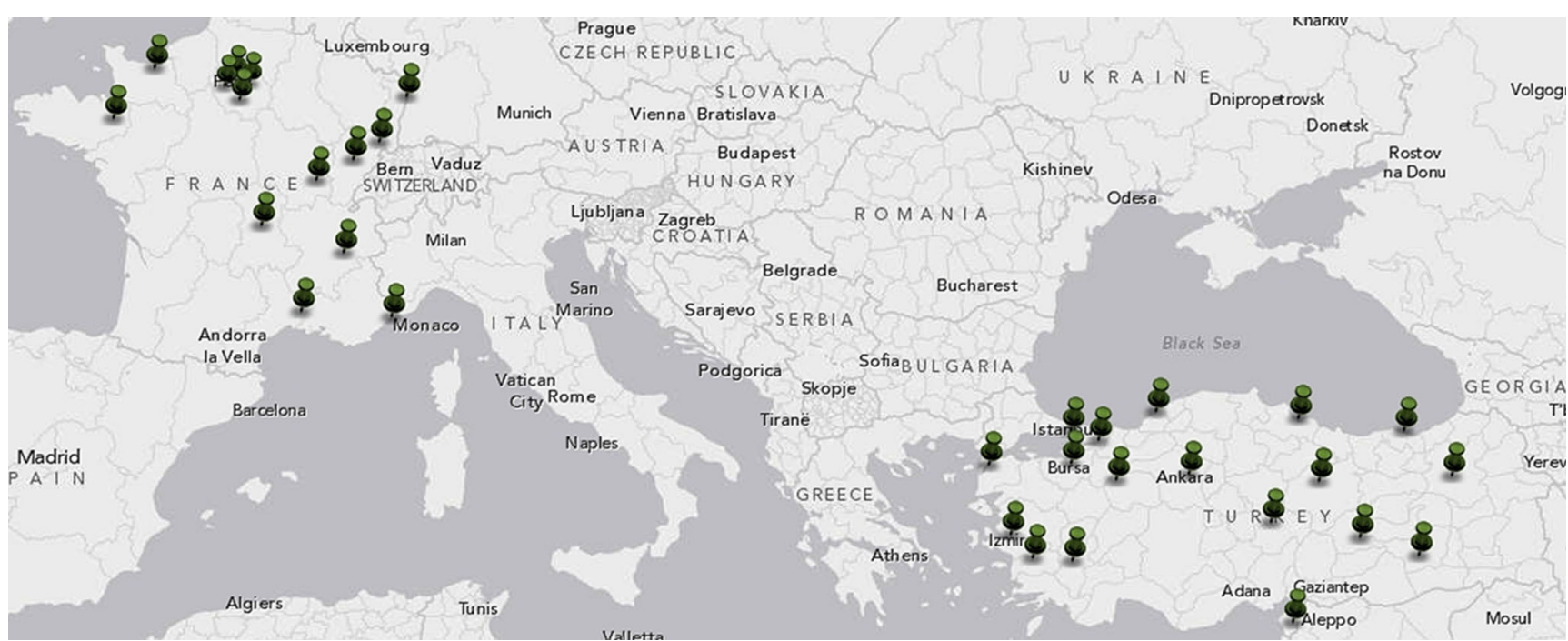

Fig. 1 The cities where the participant centers in this study are located in France and Turkey

(9.7\%)], human immunodeficiency virus (HIV) infection [10 (4\%) vs. $44(13.7 \%)$ ], and infective endocarditis [3 (1.2\%) vs. $27(8.4 \%)]$ were significantly more frequent in France $(p<0.05$ for all). On the other hand, skin and soft tissue infections [39 $(15.7 \%)$ vs. $26(8.1 \%)]$, viral hepatitis [23 (9.3\%) vs. $3(0.9 \%)$ ], brucellosis [7 (2.8\%) vs. $0(0 \%)$, urinary tract infection $[47(19.0 \%)$ vs. $31(9.7 \%)]$, diabetic foot infection [17 (6.9\%) vs. $3(0.9 \%)$ ], and Crimean-Congo hemorrhagic fever (CCHF) [7 (2.8\%) vs. $0(0 \%)]$ were significantly more frequent in Turkish hospitals $(p<0.05$ for all). The distribution of other infections was not different. The characteristics of the patients are presented in Table 3.

\section{Antimicrobial therapy}

On the study day, 215 (78.7\%) out of 273 patients and 251 (75.5\%) out of 324 patients were given antibiotics in Turkey

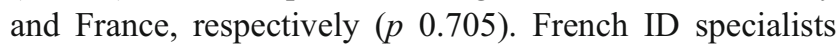
preferred to use antibiotics based on cultures and
Table 1 The features of infectious diseases (ID) departments on the study day in Turkey and France*

*Data are presented as mean \pm standard deviation (SD) or no. or no. $(\%)$

**Pulsed-field gel electrophoresis (PFGE) 1, real-time polymerase chain reaction (RT-PCR) 4

\begin{tabular}{llll}
\hline & Turkey & France & $p$-Value \\
\hline $\begin{array}{l}\text { Total number of participant centers } \\
\text { Hospital capacity }\end{array}$ & 21 & 15 & \\
$\quad$ Mean number of hospitalized patients & $763.4 \pm 351.6$ & $710.6 \pm 408.9$ & 0.712 \\
$\quad$ Mean number of hospital beds & $1,002.4 \pm 446.4$ & $1,154.6 \pm 587.9$ & 0.390 \\
The ID wards & & & \\
$\quad$ Number of patients in the ID wards & 273 & 324 & 0.005 \\
$\quad \begin{array}{l}\text { Mean number of patients in the ID wards } \\
\text { Bed occupancy rates in the ID wards }\end{array}$ & $13.4 \pm 6.4$ & $25.6 \pm 13.7$ & 0.008 \\
Status of the intensive care unit (ICU) & $13.4 / 18.0$ & $25.6 / 25.9$ & 0.376 \\
$\quad \begin{array}{l}\text { Presence of ICU room in the ID ward } \\
\text { Total number of ICU rooms in the ID wards }\end{array}$ & $4(19.0)$ & $1(6.7)$ & 0.194 \\
$\quad$ Total bed number of ICU rooms in the ID wards & 22 & $6(40.0)$ & 6 \\
Status of the negative pressure rooms (NPRs) & & & 0.025 \\
$\quad$ Total number of centers with an NPR & $3(14.3)$ & $8(53.3)$ & 1.000 \\
$\quad$ Total number of NPRs & 7 & 30 & $14(93.3)$ \\
$\begin{array}{l}\text { Presence of room oxygenation system } \\
\text { Microbiology laboratory in the ID wards** }\end{array}$ & $20(95.2)$ & $3(20.0)$ & 0.002 \\
\hline
\end{tabular}


Table 2 Comparison of the features of infection control (IC) organization in Turkey and France

$P P E$ personal protective equipment, $H C W$ healthcare worker

* Separation of domestic, medical, and sharp wastes during disposal

\begin{tabular}{llll}
\hline Variable & Turkey, $n(\%)$ & France, $n(\%)$ & $p$-Value \\
\hline Presence of IC committee & $21(100.0)$ & $15(100.0)$ & \\
Presence of IC nurse & $21(100.0)$ & $14(93.3)$ & 0.417 \\
Total number of IC nurses & 82 & 35 & \\
Presence of a certified IC nurse & $21(100.0)$ & $12(80.0)$ & 0.064 \\
Surveillance types & & & \\
By an IC nurse & $21(100.0)$ & $14(93.3)$ & 0.417 \\
Active prospective patient-based & $17(81.0)$ & $11(73.3)$ & 0.694 \\
Active prospective laboratory-based & $17(81.0)$ & $14(93.3)$ & 0.376 \\
Target-based & $18(85.7)$ & $13(86.7)$ & 1.000 \\
Invasive device-related & $21(100.0)$ & $10(66.7)$ & 0.008 \\
Management of wastes* & $20(95.2)$ & $15(100.0)$ & 1.000 \\
Cleaning of patient rooms & & & \\
Daily & $21(100.0)$ & $15(100.0)$ & \\
Due to IC committee orders & $21(100.0)$ & $14(93.3)$ & 0.417 \\
Patient rooms with a sink/patient rooms & $199 / 218$ & $294 / 309$ & 0.076 \\
Use of liquid soap in the wards & $21(100.0)$ & $14(93.3)$ & 0.417 \\
Use of supplementary material in the wards & & & 1.000 \\
Paper towels & $18(85.7)$ & $13(86.7)$ & 0.070 \\
Hand antiseptics in each room & $17(81.0)$ & $14(93.3)$ & $15(100.0)$ \\
PPE & $20(95.2)$ & $11(73.3)$ & 0.376 \\
Easy access to PPE & $9(42.9)$ & 29.5 & $6(40.0)$ \\
Mean of hand antiseptics consumed monthly (liter) & 28.4 & $20(95.2)$ & \\
Surveillance of HCWs' vaccination & & & \\
\hline
\end{tabular}

susceptibility testing more frequently [91 (42.3\%) vs. 138 $(55.0 \%)]$, while Turkish clinicians used antimicrobials significantly more often on the empirical basis [121 (56.3\%) vs. $109(43.4 \%)](p<0.05$ for both). The uses of antibiotics in both countries are presented in Table 4 .

\section{Distribution of etiological agents}

The etiological agent was confirmed microbiologically in 147 patients in Turkey and in 214 patients in France. The infecting organisms are presented in Table 5.

\section{Discussion}

In this study, the participant hospitals were quite similar and comparable in France and Turkey according to their patients and bed capacities. The presence of an intensive care unit (ICU) room and room oxygenation systems were apparently similar in the ID wards in both countries. Nevertheless, the presence of negative pressure rooms, which are used to prevent cross-contaminations [1], was significantly higher in France than in Turkey. On the other hand, the presence of microbiology laboratories in Turkish ID wards was more common than in the French ID wards. The probable reason for this was that the ID specialization was established on internal medicine training followed by ID fellowship in France [2], while Turkish specialists have a training based on integrated clinical microbiology and ID [3]. Although a central microbiology laboratory existed inside the hospitals, Turkish ID physicians preferred to perform basic and rapid tests like stains, direct microscopy, and agglutination tests in their own laboratories to prevent delays.

Surveillance, prevention, and control of infections are core activities for the ID specialists [4]. The presence of IC committees, IC nurses and their qualifications, and surveillance types performed were comparable and in accordance with the current recommendations in both France and Turkey. The only difference was that invasive device-associated surveillance, which reflects the most critical changes in hospital epidemiology and provides comparisons between the institutions [5], was performed more commonly in Turkish hospitals. This could be related to the strict regulations to survey nosocomial infections compared to the yearly evaluation in French hospitals. On the other hand, parameters related to hand hygiene, the core activity for IC control [6], the availability of personal protective equipment and their easy access, daily cleaning 
Table 3 Characteristics of infections in the ID wards
*Primary diagnoses

**All patients

\begin{tabular}{|c|c|c|c|}
\hline Variable & Turkey $(n=248), n(\%)$ & France $(n=321), n(\%)$ & $p$-Value \\
\hline \multicolumn{4}{|l|}{ Source of infections* } \\
\hline Community & $197(79.4)$ & $258(80.4)$ & \multirow{3}{*}{0.800} \\
\hline Hospital & $32(12.9)$ & $36(11.2)$ & \\
\hline Healthcare-associated & $19(7.7)$ & $27(8.4)$ & \\
\hline \multicolumn{4}{|l|}{ Severity of illness on the study day** } \\
\hline Absence of clinical sepsis & $254(93.0)$ & $272(84.0)$ & 0.001 \\
\hline Sepsis & $18(6.6)$ & $49(15.1)$ & 0.001 \\
\hline Severe sepsis & $0(0.0)$ & $2(0.6)$ & 0.503 \\
\hline Septic shock & $1(0.4)$ & $1(0.3)$ & 1.000 \\
\hline \multicolumn{4}{|l|}{ Infections* } \\
\hline Bone/joint & $18(7.2)$ & $47(14.6)$ & 0.006 \\
\hline Skin and soft tissue & $39(15.7)$ & $26(8.1)$ & 0.005 \\
\hline Viral hepatitis & $23(9.3)$ & $3(0.9)$ & $<0.001$ \\
\hline Central nervous system & $16(6.4)$ & $16(5.0)$ & 0.451 \\
\hline Tuberculosis & $12(4.8)$ & $18(5.6)$ & 0.684 \\
\hline Brucellosis & $7(2.8)$ & $0(0.0)$ & 0.003 \\
\hline Pneumonia & $8(3.2)$ & $50(15.6)$ & $<0.001$ \\
\hline Sepsis, undetermined etiology & $11(4.4)$ & $31(9.7)$ & 0.018 \\
\hline Human immunodeficiency virus infection & $10(4.0)$ & $44(13.7)$ & $<0.001$ \\
\hline Urinary tract infection & $47(19.0)$ & $31(9.7)$ & 0.001 \\
\hline Upper respiratory tract infection & $3(1.2)$ & $2(0.6)$ & 0.657 \\
\hline Diabetic foot infection & $17(6.9)$ & $3(0.9)$ & $<0.001$ \\
\hline Malaria & $1(0.4)$ & $2(0.6)$ & 1.000 \\
\hline Gastroenteritis & $2(0.8)$ & $1(0.3)$ & 0.583 \\
\hline Colitis & $0(0.0)$ & $4(1.2)$ & 0.136 \\
\hline Arbovirus infection & $1(0.4)$ & $0(0.0)$ & 0.436 \\
\hline Abscesses & $8(3.2)$ & $12(3.7)$ & 0.742 \\
\hline Measles & $3(1.2)$ & $0(0.0)$ & 0.082 \\
\hline Cytomegalovirus infections & $3(1.2)$ & $2(0.6)$ & 0.657 \\
\hline Infective endocarditis & $3(1.2)$ & $27(8.4)$ & $<0.001$ \\
\hline Syphilis & $2(0.8)$ & $0(0.0)$ & 0.190 \\
\hline Cholangitis/cholecystitis & $3(1.2)$ & $0(0.0)$ & 0.082 \\
\hline Crimean-Congo hemorrhagic fever & $7(2.8)$ & $0(0.0)$ & 0.003 \\
\hline Surgical site infection & $4(1.6)$ & $2(0.6)$ & 0.412 \\
\hline
\end{tabular}

procedures, one of the key points in reducing hospitalacquired infections [7], and separation of wastes during disposal were quite reasonable in both France and Turkey. The surveillance of HCWs for vaccination, which safeguards the personnel and protects patients from being infected through infected workers [8], was significantly higher in Turkish hospitals. However, the poor efficacy of this strategy has long been debated in Turkey [9]. Likewise, HCWs' vaccination monitoring is reported not to be organized satisfactorily in France, except the mandatory hepatitis B virus (HBV) immunization campaign. As an example, the flu vaccination rate was reported to be less than $30 \%$ in France in 2009 (http:// www.invs.sante.fr/Publications-et-outils/Rapports-et-
syntheses/Maladies-infectieuses/2011/Vaccinations-chez-lessoignants-des-etablissements-de-soins-de-France-2009). Thus, HCWs are believed to be undervaccinated in both countries.

The sources of infections and the types of infections were quite similar in both countries. However, French ID specialists followed bone and joint infections, pneumonia, sepsis with unknown etiology, HIV infection, and infective endocarditis, while Turkish clinicians treated diabetic foot infections, skin and soft tissue infections, urinary tract infections, brucellosis, viral hepatitis, and CCHF more frequently. For the Turkish side, CCHF and brucellosis are endemic and problematic issues in Turkey [10]. France is officially free of endogenous 
Table 4 The antibiotics used in the ID departments on the study day in Turkey and France
$B L / B L I$ beta-lactam/betalactamase inhibitor, $T B$ tuberculosis, TMP/SXT trimethoprimsulfamethoxazole

Anti-Gram-positive antibiotics: vancomycin, linezolid, daptomycin, and teicoplanin

\begin{tabular}{|c|c|c|c|c|}
\hline & Turkey $(n=215), n(\%)$ & France $(n=251), n(\%)$ & $p$-Value & Overall \\
\hline \multicolumn{5}{|l|}{ Use of antibiotics } \\
\hline Culture/agent-based & $91(42.3)$ & $138(55.0)$ & 0.006 & 229 \\
\hline Empirical & $121(56.3)$ & $109(43.4)$ & 0.006 & 230 \\
\hline Prophylaxis & $3(1.4)$ & $4(1.6)$ & 0.861 & 7 \\
\hline \multicolumn{5}{|l|}{ Antibiotics } \\
\hline Anti-Gram-positive & $31(14.4)$ & $21(8.4)$ & 0.039 & 52 \\
\hline Cephalosporins & $35(16.3)$ & $70(27.9)$ & 0.003 & 105 \\
\hline Carbapenems & $50(23.3)$ & $16(6.4)$ & $<0.001$ & 66 \\
\hline $\mathrm{BL} / \mathrm{BLI}$ & $33(15.3)$ & $37(14.7)$ & 0.855 & 70 \\
\hline Ciprofloxacin & $13(6.0)$ & $25(10.0)$ & 0.124 & 38 \\
\hline Penicillin/ampicillin & $5(2.3)$ & $49(19.5)$ & $<0.001$ & 54 \\
\hline Aminoglycoside & $6(2.8)$ & $26(10.4)$ & 0.001 & 32 \\
\hline Antifungals & $9(4.2)$ & $7(2.8)$ & 0.409 & 16 \\
\hline Respiratory quinolone & $5(2.3)$ & $7(2.8)$ & 0.753 & 12 \\
\hline Metronidazole & $2(0.9)$ & $18(7.2)$ & 0.001 & 20 \\
\hline Colistin & $1(0.5)$ & $3(1.2)$ & 0.628 & 4 \\
\hline Tigecycline & $9(4.2)$ & $2(0.8)$ & 0.016 & 11 \\
\hline Anti-TB & $20(9.3)$ & $12(4.8)$ & 0.054 & 32 \\
\hline Antiviral & $8(3.7)$ & $10(4.0)$ & 0.883 & 18 \\
\hline Doxycycline & $7(3.3)$ & $2(0.8)$ & 0.088 & 9 \\
\hline Rifampicin & $9(4.2)$ & $3(1.2)$ & 0.042 & 12 \\
\hline $\mathrm{TMP} / \mathrm{SXT}$ & $4(1.9)$ & $13(5.2)$ & 0.057 & 17 \\
\hline Others & $17(7.9)$ & $6(2.4)$ & NA & 23 \\
\hline
\end{tabular}

brucellosis, and recent CCHF outbreaks in Turkey and the Balkans demonstrated the transmission into the European area [11]. On the other hand, HIV infection is already known to be much more prevalent in France (http://www.avert.org/ european-hiv-aids-statistics.htm), but, surprisingly, not hepatitis B or C. In contrast, Turkish ID specialists treat chronic viral hepatitis cases according to the legal regulations for reimbursement and are quite active on this issue. However, the differences in aforementioned diagnoses were probably related to patient flow or due to the mutual concepts with other disciplines in patient sharing in both countries. Incidences of diseases, access to treatment, and cultural behaviors for hospitalizing patients may be other possible explanations.

Antibiotic use varies according to time and treatment locations [12]. In this study, the ratio of patients receiving antibiotics in the ID wards in both countries did not differ significantly. However, Turkish ID physicians prescribed a broad spectrum of antibiotics more frequently compared to French specialists. Anti-Gram-positive agents, carbapenems, and tigecycline were used significantly more often in Turkish ID wards. According to a nationwide survey, broad-spectrum antibiotic use was an issue of concern in the management of infections in ICUs in Turkey [13]. However, a relatively narrow spectrum of drugs like cephalosporins, penicillins, aminoglycosides, and metronidazole was more frequently preferred in France. The most likely reason for this difference may be the predomination of multiple and extensively resistant pathogens like Acinetobacter species, extended-spectrum beta-lactamase (ESBL)-positive enteric pathogens, and Pseudomonas aeruginosa in Turkish hospitals [10]. The current trend in medical practice in Turkey is that, while Staphylococcus aureus disappears from Turkish hospitals, Acinetobacter replaces it [14-16]. When the infecting bacteria were taken into consideration, streptococci were more frequent in France and enteric Gram-negatives in Turkey. Although the rates of ESBL-producing Gram-negative bacteria were less than $5 \%$ in community-acquired infections, and less than $15 \%$ in nosocomial infections in France (http:// www.onerba.org/IMG/pdf/ONERBA rap2009-10_CH6 sommaire.pdf), the rates of ESBL-producers in the hospitals were exceedingly high in Turkey [10]. Consequently, the resistance issue may contribute to the use of carbapenems in Turkish hospitals. Our findings correlate with another French report on antibiotic use in France with less carbapenems and more cephalosporins, penicillins, and aminoglycosides [17]. However, the frequent use of anti-Gram-positive agents may not be directly related to the requirement of these antibiotics in 
Table 5 The distribution of confirmed microorganisms as an infectious agent

\begin{tabular}{|c|c|c|c|}
\hline & Turkey, $n(\%)$ & France, $n(\%)$ & $p$-Value \\
\hline Enteric Gram-negative bacilli & $42(28.6)$ & $36(16.8)$ & 0.008 \\
\hline Pseudomonas aeruginosa & $10(6.8)$ & $12(5.6)$ & 0.641 \\
\hline Acinetobacter baumannii & $1(0.7)$ & $0(0.0)$ & 0.407 \\
\hline Aggregatibacter actinomycetemcomitans & $0(0.0)$ & $1(0.5)$ & 1.000 \\
\hline Haemophilus spp. & $1(0.7)$ & $2(0.9)$ & 1.000 \\
\hline Brucella spp. & $7(4.8)$ & $0(0.0)$ & 0.002 \\
\hline Neisseria spp. & $0(0.0)$ & $1(0.5)$ & 1.000 \\
\hline Legionella spp. & $0(0.0)$ & $2(0.9)$ & 0.516 \\
\hline Campylobacter spp. & $0(0.0)$ & $3(1.4)$ & 0.274 \\
\hline Leptospira spp. & $0(0.0)$ & $(0.5)$ & 1.000 \\
\hline Staphylococcus aureus & $19(12.9)$ & $28(13.1)$ & 0.965 \\
\hline Coagulase-negative staphylococci & $3(2.0)$ & $5(2.3)$ & 1.000 \\
\hline Streptococcus spp. & $2(1.4)$ & $29(13.6)$ & $<0.001$ \\
\hline Enterococcus spp. & $4(2.7)$ & $11(5.1)$ & 0.258 \\
\hline Corynebacterium spp. & $0(0.0)$ & $1(0.5)$ & 1.000 \\
\hline Bacillus cereus & $0(0.0)$ & $1(0.5)$ & 1.000 \\
\hline Clostridium spp. & $0(0.0)$ & $3(1.4)$ & 0.274 \\
\hline Mycobacterium tuberculosis & $9(6.1)$ & $17(7.9)$ & 0.511 \\
\hline Mycobacterium avium complex & $1(0.7)$ & $3(1.4)$ & 0.649 \\
\hline Treponema pallidum & $1(0.7)$ & $0(0.0)$ & 0.407 \\
\hline Plasmodium falciparum & $1(0.7)$ & $2(0.9)$ & 1.000 \\
\hline Aspergillus spp. & $1(0.7)$ & $1(0.5)$ & 1.000 \\
\hline Candida spp. & $2(1.4)$ & $3(1.4)$ & 1.000 \\
\hline Cryptococcus spp. & $0(0.0)$ & $1(0.5)$ & 1.000 \\
\hline Hepatitis B and C viruses & $23(15.6)$ & $3(1.4)$ & $<0.001$ \\
\hline Human immunodeficiency virus & $10(6.8)$ & $44(20.6)$ & $<0.001$ \\
\hline Rubeola virus & $3(2.0)$ & $0(0.0)$ & 0.067 \\
\hline Crimean-Congo hemorrhagic fever virus & $7(4.8)$ & $0(0.0)$ & 0.002 \\
\hline Herpes simplex virus & $1(0.7)$ & $0(0.0)$ & 0.407 \\
\hline Cytomegalovirus & $0(0.0)$ & $2(0.9)$ & 0.516 \\
\hline Jacob-Creutzfeldt virus & $0(0.0)$ & $1(0.5)$ & 1.000 \\
\hline Enterovirus & $0(0.0)$ & $1(0.5)$ & 1.000 \\
\hline Total & 147 & 214 & \\
\hline
\end{tabular}

Turkey. One aspect of our data which supports this point of view was the rate of identifying the infecting agent by culture, and subsequent treatment due to microbiological data appears to be lower in Turkey than it is in France. Consequently, Turkish ID physicians use antibiotics on an empirical basis more frequently and, thus, this style may limit the deescalation of a broad spectrum of antibiotics. Other than that, Turkey is a restructuring country and evolving legal procedures on malpractice issues are strictly enforcing clinicians for possible liability, which may facilitate the use of a broad spectrum of antibiotics.

The major limitation of this study was that the results were merely declarative, based on voluntary participation. In conclusion, both France and Turkey have established their ID departments according to their fundamental needs and historical evolutions. Today, the ID departments in both countries have common and different characteristics. Although Turkish ID departments have greater access to an internal laboratory, they less frequently document the infecting pathogens and the discrepancies in antibiotic use between both countries are striking. These differences may, indeed, be related to differences in the epidemiology of resistance and the diagnostic differences. But for many other parameters related to anti-infective management in the ID wards in France and Turkey, both countries manage the routine medical work in a satisfactory and similar fashion.

Conflict of interest We have no competing interests to declare. No funding of any kind was received. 


\section{References}

1. Humphreys H (2007) Control and prevention of healthcareassociated tuberculosis: the role of respiratory isolation and personal respiratory protection. J Hosp Infect 66(1):1-5

2. Cooke FJ, Choubina P, Holmes AH (2005) Postgraduate training in infectious diseases: investigating the current status in the international community. Lancet Infect Dis 5(7):440-449

3. Erdem H, Tekin-Koruk S, Koruk I, Tozlu-Keten D, Ulu-Kilic A, Oncul O, Guner R, Birengel S, Mert G, Nayman-Alpat S, Eren-Tulek N, Demirdal T, Elaldi N, Ataman-Hatipoglu C, Yilmaz E, Mete B, Kurtaran B, Ceran N, Karabay O, Inan D, Cengiz M, Sacar S, Yucesoy-Dede B, Yilmaz S, Agalar C, Bayindir Y, Alpay Y, Tosun S, Yilmaz H, Bodur H, Erdem HA, Dikici N, Dizbay M, Oncu S, Sezak N, Sari T, Sipahi OR, Uysal S, Yeniiz E, Kaya S, Ulcay A, Kurt H, Besirbellioglu BA, Vahaboglu H, Tasova Y, Usluer G, Arman D, Diktas H, Ulusoy S, Leblebicioglu H (2011) Assessment of the requisites of microbiology based infectious disease training under the pressure of consultation needs. Ann Clin Microbiol Antimicrob 10:38

4. Sande MA (2006) Postgraduate training in infectious diseases. Lancet Infect Dis 6(2):69

5. Richards MJ, Edwards JR, Culver DH, Gaynes RP (1999) Nosocomial infections in medical intensive care units in the United States. National Nosocomial Infections Surveillance System. Crit Care Med 27(5):887-892

6. Pittet D, Dharan S, Touveneau S, Sauvan V, Perneger TV (1999) Bacterial contamination of the hands of hospital staff during routine patient care. Arch Intern Med 159(8):821-826

7. Hughes GJ, Nickerson E, Enoch DA, Ahluwalia J, Wilkinson C, Ayers R, Brown NM (2013) Impact of cleaning and other interventions on the reduction of hospital-acquired Clostridium difficile infections in two hospitals in England assessed using a breakpoint model. J Hosp Infect 84(3):227-234

8. [No authors listed] (1997) Immunization of health-care workers: recommendations of the Advisory Committee on Immunization Practices (ACIP) and the Hospital Infection Control Practices Advisory Committee (HICPAC). MMWR Recomm Rep 46(RR-18):1-42

9. Savas E, Tanriverdi D (2010) Knowledge, attitudes and anxiety towards influenza $\mathrm{A} / \mathrm{H} 1 \mathrm{~N} 1$ vaccination of healthcare workers in Turkey. BMC Infect Dis 10:281

10. Erdem H, Akova M (2012) Leading infectious diseases problems in Turkey. Clin Microbiol Infect 18(11):1056-1067

11. Zehender G, Ebranati E, Shkjezi R, Papa A, Luzzago C, Gabanelli E, Lo Presti A, Lai A, Rezza G, Galli M, Bino S, Ciccozzi M (2013) Bayesian phylogeography of Crimean-Congo hemorrhagic fever virus in Europe. PLoS One 8(11):e79663
12. Boyles TH, Whitelaw A, Bamford C, Moodley M, Bonorchis K, Morris V, Rawoot N, Naicker V, Lusakiewicz I, Black J, Stead D, Lesosky M, Raubenheimer P, Dlamini S, Mendelson M (2013) Antibiotic stewardship ward rounds and a dedicated prescription chart reduce antibiotic consumption and pharmacy costs without affecting inpatient mortality or re-admission rates. PLoS One 8(12): e79747

13. Erdem H, Inan A, Altındis S, Carevic B, Askarian M, Cottle L, Beovic B, Csomos A, Metodiev K, Ahmetagic S, Harxhi A, Raka L, Grozdanovski K, Nechifor M, Alp E, Bozkurt F, Hosoglu S, Balik I, Yilmaz G, Jereb M, Moradi F, Petrov N, Kaya S, Koksal I, Aslan T, Elaldi N, Akkoyunlu Y, Moravveji SA, Csato G, Szedlak B, Akata F, Oncu S, Grgic S, Cosic G, Stefanov C, Farrokhnia M, Müller M, Luca C, Koluder N, Korten V, Platikanov V, Ivanova P, Soltanipour S, Vakili M, Farahangiz S, Afkhamzadeh A, Beeching N, Ahmed SS, Cami A, Shiraly R, Jazbec A, Mirkovic T, Leblebicioglu H, Naber K (2014) Surveillance, control and management of infections in intensive care units in Southern Europe, Turkey and Iran - a prospective multicenter point prevalence study. J Infect 68(2):131-140

14. Erdem H, Dizbay M, Karabey S, Kaya S, Demirdal T, Koksal I, Inan A, Erayman I, Ak O, Ulu-Kilic A, Karasahin O, Akbulut A, Elaldi N, Yilmaz G, Candevir A, Gul HC, Gonen I, Oncul O, Aslan T, Azak E, Tekin R, Kocak Tufan Z, Yenilmez E, Arda B, Gungor G, Cetin B, Kose S, Turan H, Akalin H, Karabay O, Dogan-Celik A, Albayrak A, Guven T, Celebi G, Ozgunes N, Ersoy Y, Sirmatel F, Oztoprak N, Balkan II, Bayazit FN, Ucmak H, Oncu S, Ozdemir D, Ozturk-Engin D, Bitirgen M, Tabak F, Akata F, Willke A, Gorenek L, Ahmed SS, Tasova Y, Ulcay A, Dayan S, Esen S, Leblebicioglu H, Altun B, Unal S (2013) Withdrawal of Staphylococcus aureus from intensive care units in Turkey. Am J Infect Control 41(11):1053-1058

15. Inan A, Ozgultekin A, Akcay SS, Engin DO, Turan G, Ceran N, Dincer E, Aksaray S, Goktas P, Erdem I (2012) Alterations in bacterial spectrum and increasing resistance rates in isolated microorganisms from device-associated infections in an intensive care unit of a teaching hospital in Istanbul (2004-2010). Jpn J Infect Dis 65(2): $146-151$

16. Tunger Ö, Keleș G, Șebnem SȘ, Çetin ÇB, Gazi H, Sümeyra SÇ, Aras İ, Çivi M (2013) Risk factors for nosocomial Acinetobacter bacteremia: a case-control study of intensive care unit patients. J Microbiol Infect Dis 3(4):157-162

17. Robert J, Péan Y, Varon E, Bru JP, Bedos JP, Bertrand X, Lepape A, Stahl JP, Gauzit R; Société de pathologie infectieuse de langue française (SPILF); Observatoire national de l'épidémiologie de la résistance bactérienne aux antibiotiques (ONERBA); Surveillance de la prescription des antibiotiques (SPA) Group (2012) Point prevalence survey of antibiotic use in French hospitals in 2009. J Antimicrob Chemother 67(4):1020-1026 